\title{
Sociocultural factors in the success of Vietnamese English learners
}

\author{
Tran Vo, MA TESOL student \\ t.vo011@westcliff.edu
}

\begin{abstract}
This research paper analyzes the current English learning and teaching situation in Vietnam through collated data from both primary and secondary sources. The primary sources were taken from the survey entitled, "Factors influencing Vietnamese learners' success in learning English" (see Appendix A). The survey asked participants to describe their demographics and opinions about teaching and learning English in Vietnam. The participants consisted of the author's living and teaching network, which was comprised of $31.8 \%$ acquaintances and $68.2 \%$ students at the Premier Language School. The secondary sources were compiled from scholarly articles, news, books, and online sources. These sources provide a broad scope when looking into the country's identified issues concerning English learning and teaching.
\end{abstract}




\section{Introduction}

President Bill Clinton lifted the nineteen-year-old trade embargo against Vietnam on February 3, 1994 (Cockburn, 1994). This was a great threshold of the Vietnamese socioeconomic development. One year later, in a review in The New York Times, Mydans (1995) wrote:

Twenty years after the end of the war and the disappearance of Americans from Vietnam, this Communist country is in the throes of an English-language boom that has little to do with the past and everything to do with the nation's rush to join the international marketplace. The war seems all but forgotten as ordinary Vietnamese welcome American visitors not as former soldiers but as future investors.

It has been twenty-two years since the early advancement of the English language, and Vietnam has witnessed a lot of far reaching contributions and achievements in teaching and learning English. According to Education First (EF), the English Proficiency Index (EPI) places Vietnam thirty-first out of the seventy-two countries reviewed in terms of the ranking of language proficiency among Vietnam's adult population (2017). This information confirms an improvement from 2.13 points to 55.94 points compared to last year's index. This is a positive sign for the country's general situation regarding teaching and learning English. However, the feelings of positivity are still controversial among Vietnamese people, who may quickly voice dissatisfaction regarding the general environment of English teaching and learning. Therefore, this paper seeks to discover what Vietnamese English learners truly think about the issue for a more impartial look, which can be the fundamental to the quality of English teaching throughout the country.

Research Findings

Secondary Sources

The English language in the Vietnamese society.

Vietnam is a Far East Asian country with the long tradition respect for teachers and ethics. This beautiful humane value has been embraced and developed throughout many generations. The dedication to respect is found across the country, from rural to urban areas and from remote villages to economic-financial centers. The Vietnamese government has 
always emphasized the importance of enhancing foreign language levels among the citizens, especially the English language, which is in part why it is such a respected profession.

\section{A bright and clear picture.}

According to the current data recorded by EF's EPI, the level of proficiency has increased considerably in Vietnam throughout the previous few years. The following figures give strong evidence to support that claim.

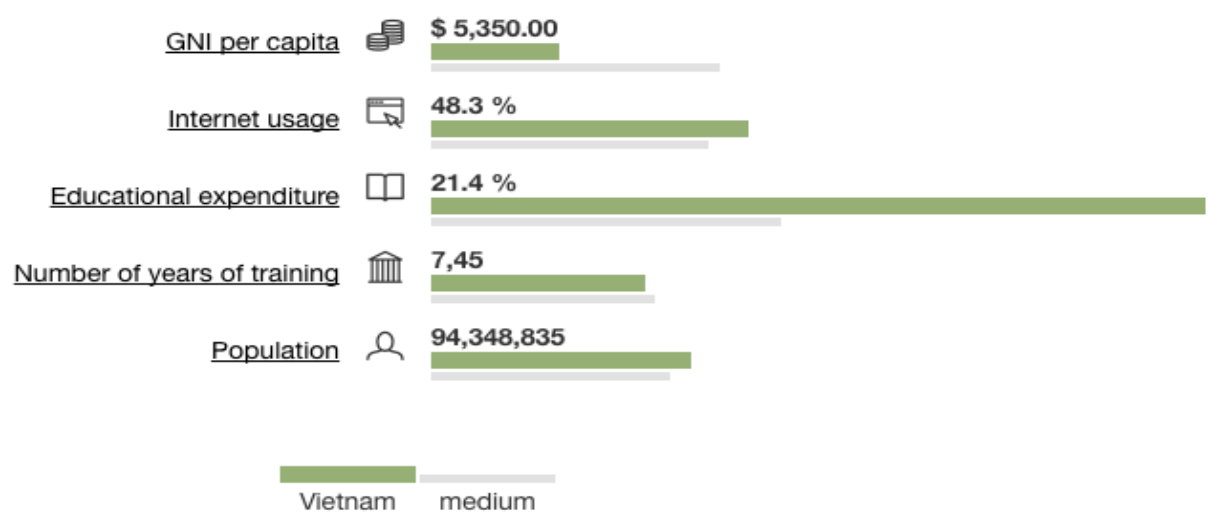

Figure 1. Summary of Vietnamese teaching and learning English. Reprinted from EF EPI in EF Education First, n.d. Retrieved July 16, 2017, from http://www.ef.com.vn/epi/regions/asia/vietnam/. Copyright 2017 by EF Education First. Adapted with permission.

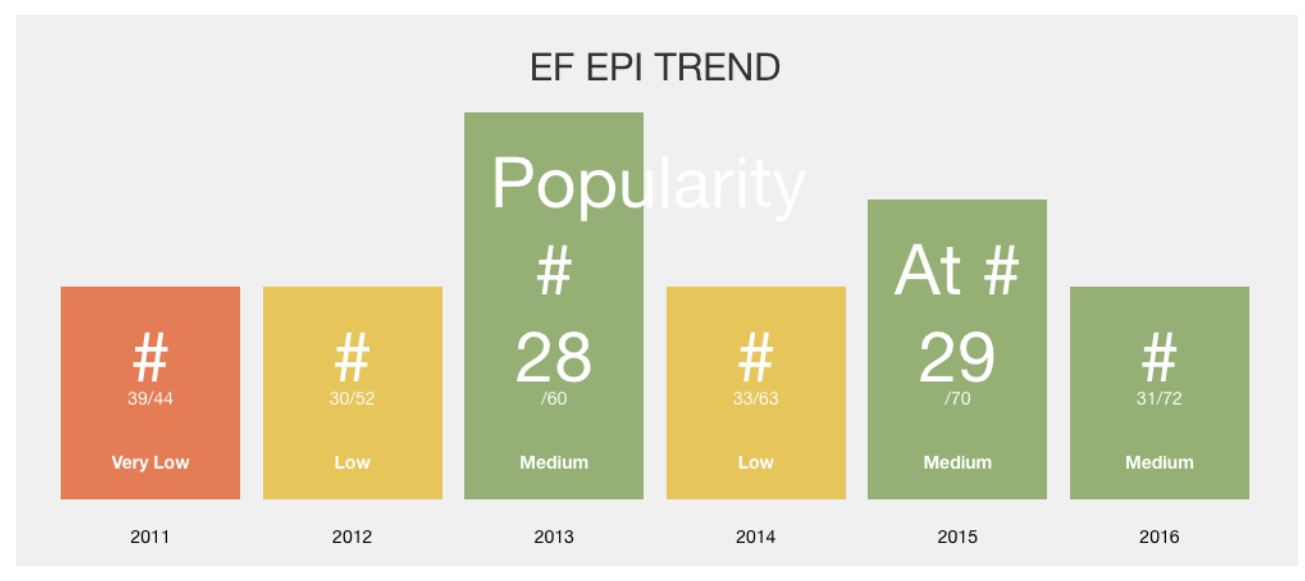

Figure 2. EF EPI Trend in Vietnam. Reprinted from EF EPI

in EF Education First, n.d. Retrieved July 16, 2017, from http://www.ef.com.vn/epi/regions/asia/vietnam/.

Copyright 2017 by EF Education First. Adapted with permission. 
English proficiency in Vietnam has improved recently, which lends to a belief that there has been an improvement in the quality of teaching, and thus, learning. The Economist (2011) expressed that, "The quality of English instruction in Vietnam lags far behind government aspirations" (para. 1). In 2012, Vietnam's ranking increased by seventeen despite the fact that the country was still in the "low" group. By 2013, the country's ranking had steadily increased to twenty-eight out of sixty countries total. In the 2014-2016 period, the country's English language ranking made stable steps and stood at the "medium" level out of the five identified possible levels: very high, high, medium, low, very low. In 2016, Vietnam proudly was ranked one space below Hong Kong, an old English colony with high proportions of English speakers. Optimistically speaking, Vietnam's ranking could be in "high" in near future.

\section{Regional comparison.}

Vietnam is one of the three nations in Indochina, along with Cambodia and Laos, that were affected by the war and the socio-economic conditions that arose because of it. This had a direct impact on the ranking of these identified countries for many years. Vietnam has only just risen surpassed the rankings of Laos and Cambodia.

Table 1

English proficiency comparison in 2016 (Indochina)

\begin{tabular}{|l|l|l|}
\hline Vietnam & Laos & Cambodia \\
\hline Rank 31 & Rank 70 & Rank 69 \\
\hline EF EPI Rating: 54.06 & EF EPI Rating: 38.45 & EF EPI Rating: 39.48 \\
\hline High & Very low & Very low \\
\hline
\end{tabular}

Note: Reprinted from EF EPI in EF Education First, n.d. Retrieved July 16, 2017, from http://www.ef.com.vn/epi/compare/regions/vn/kh/. Copyright 2017 by EF Education First.

Judging the position of Vietnam in Figure 3 below, gives more insight in terms of its overall ranking. Vietnam's English proficiency rate is ranked within the top ten of all countries within the continent of Asia. Asia only has one country which has a "very high" EPI rating Singapore, where English is the official language. Vietnam is even ranked before some more developed countries, such as Japan, China, and Thailand. 


\section{EF EPI Average: \\ 55.94}

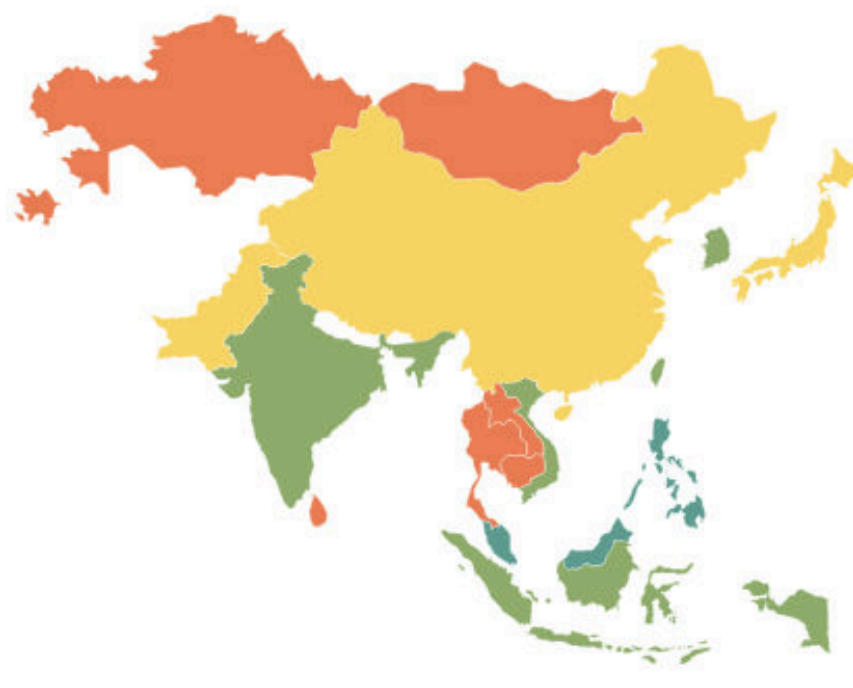

LEVELS OF PROFICIENCY:

Very high High medium Low Very low

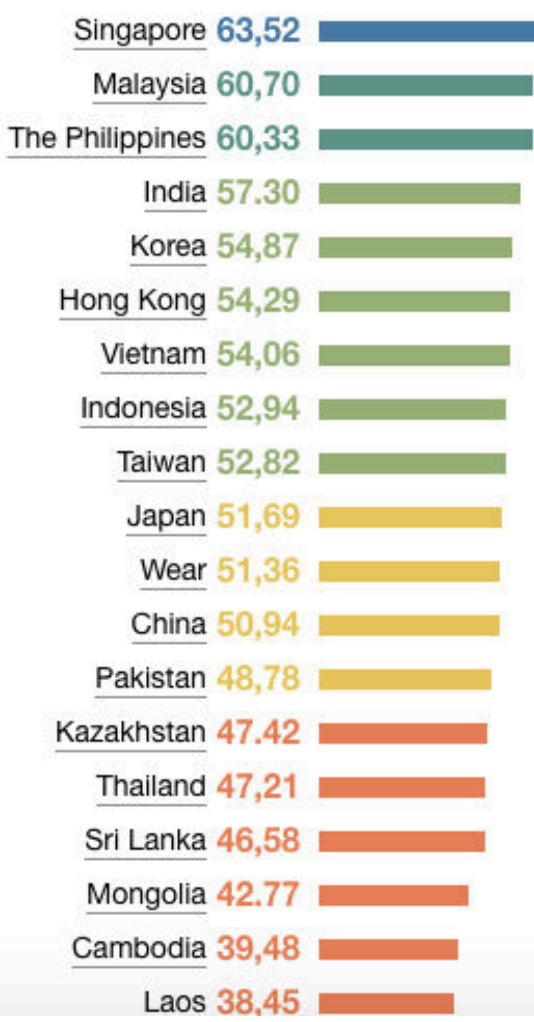

Laos 38,45

Figure 3. EF EPI Trend in Vietnam. Reprinted from EF EPI

in EF Education First, n.d. Retrieved July 16, 2017, from http://www.ef.com.vn/epi/. Copyright 2017 by EF Education First. Adapted with permission.

\section{Primary sources}

\section{Data collection.}

The primary sources provide information regarding the research of this author's current living and teaching context. Among the forty-four participants surveyed, fourteen (31.8\%) were friends with the author who have learned or are in the process of learning English as a second language. The remaining participants (68.2\%) were students currently enrolled in the Premier Language School. The participants were asked to describe their location, age group, financial position, and English certificates earned. The questions were in multiple-choice format. The findings have been summarized in the table below.

Demographic factors. 
Table 2

Vietnamese English Learners' demographics

\begin{tabular}{|c|c|}
\hline 1. Genders & 44 subjects $=100 \%$ \\
\hline Male & $25 \%$ \\
\hline Female & $72.70 \%$ \\
\hline Undefined & $2.30 \%$ \\
\hline 2. Occupations & 44 subjects $=100 \%$ \\
\hline Office worker & $25 \%$ \\
\hline Student & $50 \%$ \\
\hline Education & $18.20 \%$ \\
\hline Self-employed & $0 \%$ \\
\hline Manual labor & $2.30 \%$ \\
\hline Housewife & $2.30 \%$ \\
\hline Business owner & $2.30 \%$ \\
\hline 3. Age groups & 44 subjects $=100 \%$ \\
\hline Under 20 & $25 \%$ \\
\hline $20-35$ & $68.20 \%$ \\
\hline $35-50$ & $6.80 \%$ \\
\hline Over 50 & $0 \%$ \\
\hline 4. Place of living & 44 subjects $=100 \%$ \\
\hline Ho Chi Minh City & $88.60 \%$ \\
\hline Hanoi City & $0 \%$ \\
\hline Da Nang City & $0 \%$ \\
\hline Other & $11.40 \%$ \\
\hline 5. Financial Abilities & 44 subjects $=100 \%$ \\
\hline Low & $18.20 \%$ \\
\hline Average & $81.80 \%$ \\
\hline
\end{tabular}


TOEFL

TOEIC

$52.27 \%$

IELTS

CPE

Other

No certificates

There were more female learners $(72.7 \%)$ than male learners (25\%) surveyed, with the undefined-gender learners encompassing $2.3 \%$. The majority of learners were adolescents of the $20-35$ age group (68.2\%), followed by $25 \%$ of learners who were under twenty years old. $88.6 \%$ of the subjects are living in Ho Chi Minh City, $11.4 \%$ in other cities, although none of the participants were living in either of the other two largest cities in Vietnam, Hanoi and Da Nang. $81.8 \%$ of the subjects fall within the average range of financial status, whereas $18.2 \%$ value their finance status as "low." No participants identified having a "high" financial status. English certificates, a reflection of a learner's qualifications, were also included in the survey. TOEIC ${ }^{\circledR}$ was the most popular certificate, which was earned by $52.27 \%$ of participants.11.36\% received an IELTS ${ }^{\circledR}$ certificate, $6.82 \%$ received a TOEFL ${ }^{\circledR}$ and CPE $^{\circledR}$ certificate, and $22.73 \%$ identified receiving other certificates. $18.18 \%$ participants did not receive any certificates.

Attitudes and learning methods.

In the next part of the survey, the participants were asked about their opinions and judgments regarding attitudes, learning methods, family and teachers' support, teachers' qualifications, and overall satisfaction. Questions were given in an open-ended format with some embedded within the Linkert scale. 
Table 3

Vietnamese learners' attitude towards learning English

\section{Attitude towards learning English}

\begin{tabular}{|c|c|}
\hline 6.1 Spending & 44 subjects $=100 \%$ \\
\hline No more than $10 \%$ of my income & $27.30 \%$ \\
\hline No more than $20 \%$ of my income & $34.10 \%$ \\
\hline No more than $30 \%$ of my income & $25 \%$ \\
\hline No more than $50 \%$ of my income & $13.60 \%$ \\
\hline 6.2 The importance of English & 44 subjects \\
\hline It is a necessary universal language. & $79.50 \%$ \\
\hline It is popular, but not the most. & $11.40 \%$ \\
\hline It helps me get my desired job. & $81.80 \%$ \\
\hline It is compulsory to learn English. & $36.40 \%$ \\
\hline English proficiency is unessential. & $4.50 \%$ \\
\hline I must be English-competent for university graduation. & $22.70 \%$ \\
\hline
\end{tabular}

6.3 English (L2) interference

44 subjects

Its vast knowledge

$31.80 \%$

Its complicated grammar and structure

$50 \%$

Its large vocabulary

$70.50 \%$

Its difficult accents

$36.40 \%$

Its writing styles

$25 \%$

Its diversity

$34.10 \%$

\subsection{Purposes}

44 subjects

Well-paid jobs

$54.50 \%$

Better international communication

$63.60 \%$

More business opportunities

$43.20 \%$

Higher positions in the workplace

$50 \%$ 
Better entertainment (more access to books, movies,

etc.)

$31.80 \%$

A hobby

$29.50 \%$

6.5 Personal difficulties
Lack of time
Too much homework
Lack of money
Lack of good schools
Inadequate teaching methods
Lack of motivation
6.6 The most important contribution factor in
success/failure

Teachers' quality

44 subjects $=100 \%$

Self-learning ability

$9.10 \%$

Motivation

$36.40 \%$

Learning methods

$22.70 \%$

Teaching methods

$15.90 \%$

Facilities

$13.60 \%$

$2.30 \%$

\section{7\% Time (per week) spent on learning English}

$$
30 \text { subjects }=100 \%
$$

less than 7 hours

$36.70 \%$

7 to 14 hours

$26.70 \%$

over 14 hours

$36.60 \%$

In terms of the participants' attitudes regarding cost of courses, $34.1 \%$ of participants were willing to spend no more than $20 \%$ of their income on learning English. The other 27.3\%, $25 \%$, and $13.6 \%$ of learners were willing to spend $10 \%, 30 \%$, and $50 \%$ on English courses respectively. The general attitude in Vietnam regards learning English as important because it helps them to get their desired jobs ( $81.8 \%$ of participants validated this claim). $79.5 \%$ of 
participants surveyed identified that their reason to learn English was because it is a universal language. $36.4 \%$ of learners believed it was compulsory to learn English. $22.7 \%$ needed to prove competence in English to graduate from university. Only 4.5\% agreed that English proficiency was unnecessary.

In terms of the purpose behind learning English, the majority of those surveyed (63.6\%) identified international communication as the main reason. Secondly, 54.5\% identified securing well-paid jobs as their purpose, $50 \%$ of the participants believed it would help them get promoted in their career, and $43.2 \%$ believed it would provide them with more business opportunities. 31.8\% identified their purpose for learning English was to access better entertainment. $29.5 \%$ stated that they learn English as a hobby.

In regard to problems associated with learning English, two aspects were selected: English interference and personal difficulties. $70.5 \%$ agreed that large vocabulary necessary was the biggest problem. 50\% were afraid of its complex grammar and structure. The need for vast knowledge, ability to understand difficult accents, and diversity were chosen by $31.8 \%, 36.4 \%$, and $34.1 \%$ of participants respectively. The subjects' personal difficulties were various with lack of time being the biggest obstacle (56.8\%). The second major hindrance was lack of money (22.7\%). "Too much homework" and "inadequate learning methods" were equally selected at 15.9\%. "Lack of motivation" was identified as a popular problem amongst $20.5 \%$ participants, and the least common problem chosen was lack of quality schools at $6.8 \%$.

$36.4 \%$ of participants identified the ability to self-learn as the driving factor of success in learning English. 22.7\% identified the leading factor as motivation. Learning and teaching methods were chosen by $15.9 \%$ and $13.6 \%$ of participants respectively. Only $9.1 \%$ agreed that the quality of a teacher was significant in their success. "Facilities" did not seem to be valued with only $2.3 \%$ of participants identifying that this was a factor of success.

Around one third of the participants spent less than seven hours per week studying English. $36.6 \%$ spent more than fourteen hours a week studying, and $26.67 \%$ dedicated seven to fourteen hours.

Learning methods. 
Another part of the survey focused on Vietnamese learners' learning methods. The findings are shown in Table 4. Nearly half of the participants felt confident in their self-learning abilities (47.7\%). $31.8 \%$ could not identify their self-learning ability, and $20.5 \%$ were not confident in this regard. When asked about reactions in class when not understanding a point, most subjects expressed that they would raise their questions immediately (54.5\%), and 25\% voiced that they prefer to save their questions until the end of class. $15.9 \%$ agree that they choose to figure the answers out by themselves later, and only $4.5 \%$ expressed that they feel shy to ask a question in front of the class.

Regarding ways to improve their English skills, half of the subjects decided to enroll in a language center. Nearly $16 \%$ watch movies in English, while $13.7 \%$ go traveling. $11.3 \%$ listen to English, and 6.8\% read books in English. Only 2.3\% try to find English tutors.

Table 4

Learning methods

\section{Learning methods}

\begin{tabular}{lr}
\hline 7.1 Confidence in self-learning ability & 44 subjects $=\mathbf{1 0 0 \%}$ \\
\hline Yes & $47.70 \%$ \\
No & $20.50 \%$ \\
Maybe & $31.80 \%$ \\
\hline 7.2 Reactions when not understanding a point in class & $\mathbf{4 4}$ subjects $=\mathbf{1 0 0 \%}$ \\
\hline Raise my question immediately. & $54.50 \%$ \\
Wait until the end of the class since I want to ask more. & $25 \%$ \\
Wait until the end of the class since I am shy. & $15.90 \%$ \\
I will figure it out by myself. & $\mathbf{4 4}$ subjects $=\mathbf{1 0 0 \%}$ \\
\hline 7.3 Ways to improve English skills & $50 \%$ \\
\hline Go to a language center & $2.30 \%$ \\
Seek for an English tutor & $15.90 \%$
\end{tabular}


Listen to English songs

$11.30 \%$

Go Traveling

$13.70 \%$

Read books in English

$6.80 \%$

Family and school factors.

Table 5 shows the subjects' responses to questions about factors related to family and school. Some high school students in the subjects were asked to give answers in a Likert scale about their satisfaction with the quality of their high school's English courses as well as their personal results.

$84.1 \%$ of the participants identified that they were supported by their families, yet $15.9 \%$ claimed to get no family support. Among the types of support referred to, "financial support" was selected as the most popular form (70.2\%). Mental and physical support were chosen at $19.1 \%$ and $10.6 \%$ respectively.

$55.8 \%$ of participants agree that they received support from their English teachers.

$34.1 \%$ expressed high satisfaction with teachers' support. $6.8 \%$ gave neutral answers. Only $4.6 \%$ identified their teacher's support as being bad or very bad.

The results of the surveyed high school students in terms of their satisfaction in their performances were as follows: $44.4 \%$ of the students agreed and $33.3 \%$ strongly agreed that they were happy with their results as well as with the quality of their courses. Still, $16.7 \%$ were dissatisfied and $5.6 \%$ remained neutral. 
Table 5

Family and school support

\begin{tabular}{|c|c|}
\hline \multicolumn{2}{|l|}{ 8. Family support } \\
\hline 8.1 Yes/No & 44 subjects $=100 \%$ \\
\hline Yes & $84.10 \%$ \\
\hline No & $15.90 \%$ \\
\hline 8.2 Major support & 44 subjects $=100 \%$ \\
\hline Financial & $70.20 \%$ \\
\hline Mental & $19.10 \%$ \\
\hline Physical & $10.60 \%$ \\
\hline 9. Teachers' support & 44 subjects $=100 \%$ \\
\hline Very bad & $2.30 \%$ \\
\hline Bad & $2.30 \%$ \\
\hline Neutral & $14 \%$ \\
\hline Good & $55.80 \%$ \\
\hline Very good & $25.60 \%$ \\
\hline 10. Teachers' qualification & 44 subjects $=100 \%$ \\
\hline Very bad & $2.30 \%$ \\
\hline Bad & $2.30 \%$ \\
\hline Neutral & $6.80 \%$ \\
\hline Good & $54.50 \%$ \\
\hline Very good & $34.10 \%$ \\
\hline $\begin{array}{l}\text { 11. High schools' good teac } \\
\text { satisfaction in results }\end{array}$ & 18 subjects $=100 \%$ \\
\hline Strongly disagree & $0 \%$ \\
\hline Disagree & $16.70 \%$ \\
\hline Neutral & $5.60 \%$ \\
\hline Agree & $44.40 \%$ \\
\hline Strongly agree & $33.30 \%$ \\
\hline
\end{tabular}

\section{Conclusion}

The reliable information shown through the secondary sources cited has clearly shown that English language proficiency has developed throughout Vietnam. The country's traditions and customs have always supported teaching and learning English. The improvement in the EF EPI ranking indicates a promising future for the Vietnam's rate of English acquisition. Compared to other countries in Indochina, Asia, and the world, Vietnam has been progressing at a consistent rate in terms of English proficiency. 
The survey given reflects a small but bright picture of English learning and teaching in Vietnam. The opinions of English learners show overarching satisfaction, in spite of some dissatisfaction.

In particular, the majority of learners identify their "self-learning ability" as the main determinant in their success, meaning an educator's role should be focused on guiding them towards how to improve their self-learning skills. Furthermore, the fact that most learners are not confident in their self-learning abilities and choose going to language centers to improve their English skills proves that language centers in Vietnam need to improve their teaching quality to help learners solve these problems.

In order to assist learners in overwhelming obstacles regarding learning English, language centers and/or English teachers should design appropriate curricula. Specifically, "lack of time" is chosen as a major personal problem, so the amount of homework should not make the students feel overwhelmed or burdened. Instead, teachers should focus on a specific target and limit the amount of homework students need to do to practice that target language. With regard to English interference, curriculum should focus on effective vocabulary learning methods since vocabulary was identified as the biggest problem in learning the language. Besides, more pronunciation classes should be offered as many learners are afraid of difficult English accents.

Taking into account learners' attitudes towards learning English, the learners were aware of the importance of English in that it helps develop their career. Therefore, curricula should be career focused. Even though most surveyed learners agree that learning English is compulsory, and it is a universal language, only $36.6 \%$ of them spend more than fourteen hours per week learning English, which equates to two hours a day.

The majority of participants showed satisfaction when asked about their high schools' teaching quality and English learning results. However, there were concerns regarding the teaching quality. The quality of teaching remains a complex issue, as Parks (2011) projects that "all school leavers will have a minimum level of English by 2020 under ambitious education reforms, but teachers fear that they are not getting the help they need to upgrade their own skills". Teacher training remains the trickiest aspect in improving the quality of teaching. That is 
why teachers themselves should improve their qualifications and experience rather than waiting for governmental support. 


\section{Appendix A}

Factors Influencing Success in Vietnamese Learners' English Learning Hello everybody, I am conducting a survey on the factors that affect Vietnamese students' English learning performances. Your time spent on answering this questionnaire is valuable. Thank you very much.

1. You are
Male
Female
Undefined

2. What can your occupation be classified as?

Office worker

$\square$ Student

$\square$ Education

Self-employed

Manual labor

$\square$ Housewife

Business owner

3. How old are you?

Under 20

20-35

35-50

over 50

4. Where are you living now?

$\square$ Ho Chi Minh City

Hanoi City

Da Nang City

Other

5. How would you judge your financial ability? (including parental support)

Low

Average

High

6. How much would you spend on learning English?

No more than $10 \%$ of my income

No more than $20 \%$ of my income

No more than $30 \%$ of my income

No more than $50 \%$ of my income

7. What is your opinion about the importance of English? (You can choose more than one option)

It is a necessary universal language.

$\square$ It is popular, but not the most.

$\square$ It helps me get my desired job.

$\square$ It is compulsory to learn English.

English competence is enough, and English proficiency is unessential. 
I must be English-competent for university graduation.

8. Do you have any English certificates? (If yes, please go to question 9)

$\square$ Yes

No

9. What is (are) your English certificate(s)? (You can choose more than one option)
TOEFL
TOEIC
$\square$ IELTS
$\square \mathrm{CPE}$
$\square$ Other

10. Do/Did you have family support in learning English? (If yes, please go to question 11)

Yes $\square$ No

11. What is the major support they give/gave you?

$\square$ Financial (paying your fees, etc.)

Mental (encouraging you, etc.)

Physical (picking you up from school, taking care of you, etc.)

12. What are the difficulties in learning English? (You can choose more than one option)

$\square$ Its vast knowledge

$\square$ Its complicated grammar and structure

$\square$ Its large vocabulary

$\square$ Its difficult accents

$\square$ Its writing styles

$\square$ Its diversity

13. What is/are your purpose(s) of learning English? (You can choose more than one option)

Well-paid jobs

Better international communication

More business opportunities

Higher positions in the work place

Better entertainment (more access to books, movies, etc.)

A hobby

14. What are your own difficulties in learning English? (You can choose more than one option)

Lack of time

Too much homework

Lack of money

Lack of good schools

Inadequate teaching methods

Lack of motivation

15. What do you do to improve you English skills?

$\square$ Go to a language center

Seek for an English tutor

Watch movies in English

$\square$ Listen to English songs

Go Traveling

Read books in English 
16. What is the most important contribution factor in your success/failure in learning English?

$\square$ Teachers' quality

$\square$ Self-learning ability

Motivation

Learning methods

Teaching methods

Facilities

17. What do you do when you do not understand a point during the class time?

$\square$ Raise my question immediately.

Wait until the end of the class since I want to ask more.

Wait until the end of the class since I am shy.

I will figure it out by myself.

18. Your teacher gives/gave you good support.

$\square$ Strongly disagree $\square$ Disagree $\square$ Neutral $\square$ Agree $\square$ Strongly agree

19. Your teacher(s) is/are qualified

$\square$ Strongly disagree $\square$ Disagree $\square$ Neutral $\square$ Agree $\square$ Strongly agree

20. Are you confident in your self-learning ability?

$\square$ Yes $\square$ No $\square$ Maybe

21. (Please answer this if you are a high school student) Your school is offering good teaching methods and you are happy with you results.

Strongly disagree $\square$ Disagree $\square$ Neutral $\square$ Agree $\square$ Strongly agree

22. How much time per week do you spend on learning English?

$\square$ less than 7 hours

7 to 14 hours

over 14 hours 


\section{REFERENCES}

EF English proficiency index. (2016). EF EPI. Retrieved from http://www.ef.com.vn/epi/ Cockburn, P. (1994). US finally ends Vietnam embargo. Retrieved from http://www.independent.co.uk/news/world/us-finally-ends-vietnam-embargo1391770.html

I am English teach. (2011). The Economist. Retrieved from https://www.economist.com/blogs/johnson/2011/09/english-vietnam

Mydans, S. (1995). The world: Vietnam speaks English with an eager accent. Retrieved from http://www.nytimes.com/1995/05/07/weekinreview/the-world-vietnam-speaksenglish-with-an-eager-accent.html

Parks, E. (2011). Vietnam demands English language teaching 'miracle'. Retrieved from https://www.theguardian.com/education/2011/nov/08/vietnam-unrealistic-englishteaching-goals

Tran, T. T., Baldauf J., \& Richard, B. (2007) Demotivation: Understanding resistance to English language learning - The case of Vietnamese students. The Journal of Asia TEFL, 4(1), 79105. Retrieved from https://espace.library.uq.edu.au/view/UQ:23743

Tran, T. T. (2013). Factors affecting teaching and learning English in Vietnamese universities. The Internet Journal Language, Culture and Society, 38 (1), 138145. Retrieved from file:///Users/phuongdo/Downloads/16.\%20Thi\%20Tuyet\%20Tranok.pdf 